\title{
Brain-Derived Neurotrophic Factor Inhibits Calcium Channel Activation, Exocytosis, and Endocytosis at a Central Nerve Terminal
}

\author{
Maryna Baydyuk, ${ }^{\star}$ Xin-Sheng Wu, ${ }^{\star}$ Liming He, and Ling-Gang Wu \\ National Institute of Neurological Disorders and Stroke, Bethesda, Maryland 20892
}

Brain-derived neurotrophic factor (BDNF) is a neurotrophin that regulates synaptic function and plasticity and plays important roles in neuronal development, survival, and brain disorders. Despite such diverse and important roles, how BDNF, or more generally speaking, neurotrophins affect synapses, particularly nerve terminals, remains unclear. By measuring calcium currents and membrane capacitance during depolarization at a large mammalian central nerve terminal, the rat calyx of Held, we report for the first time that BDNF slows down calcium channel activation, including $\mathrm{P} / \mathrm{Q}$-type channels, and inhibits exocytosis induced by brief depolarization or single action potentials, inhibits slow and rapid endocytosis, and inhibits vesicle mobilization to the readily releasable pool. These presynaptic mechanisms may contribute to the important roles of BDNF in regulating synapses and neuronal circuits and suggest that regulation of presynaptic calcium channels, exocytosis, and endocytosis are potential mechanisms by which neurotrophins achieve diverse neuronal functions.

Key words: BDNF; calcium channels; calyx of Held; endocytosis; exocytosis

\section{Introduction}

Molecules regulating synaptic transmission critically affect brain function. One such molecule is brain-derived neurotrophic factor (BDNF), a neurotrophin that regulates various neuronal functions via activation of tropomyosin-related kinase B (TrkB) (Reichardt, 2006). For instance, BDNF potentiates (Kang and Schuman, 1995; Carmignoto et al., 1997) or inhibits (Tanaka et al., 1997; Frerking et al., 1998; Clark et al., 2011) synaptic transmission, enhances long-term potentiation, a cellular substrate for learning and memory (Minichiello et al., 1999), promotes synapse formation (Vicario-Abejón et al., 1998), and changes the number and volume of dendritic spines (Orefice et al., 2013). These synaptic effects may contribute to the overall effect of BDNF on neuronal survival, differentiation, axonal branching, and dendritic growth (Huang and Reichardt, 2001; Park and Poo, 2013). Deletion of either the TrkB or Bdnf gene leads to cell atrophy, dendritic degeneration, and neuronal loss (Xu et al., 2000b; Gorski et al., 2003). Importantly, deficiency in BDNF signaling has been implicated in neurodevelopmental, neurodegenerative, and neuropsychiatric disorders (Zuccato and Cattaneo, 2009;

Received July 2, 2014; revised Jan. 28, 2015; accepted Feb. 2, 2015

Author contributions: M.B. and L.-G.W. designed research; M.B., X.-S.W., and L.H. performed research; M.B. and X.-S.W. analyzed data; M.B. and L.-G.W. wrote the paper.

This research was supported by the National Institute of Neurological Disorders and Stroke Intramural Research Program. We thank Dr. Baoji Xu for reagents and Bdnf ${ }^{L a C Z /+}$ and TrkB ${ }^{\text {LaCZ/+ }}$ brains.

*M.B. and X.-S.W. authors contributed equally to this work.

The authors declare no competing financial interests.

Correspondence should be addressed to Ling-Gang Wu, National Institute of Neurological Disorders and Stroke,

35 Convent Drive, Building 35, Room 2B-1012, Bethesda, MD 20892. E-mail: wul@ninds.nih.gov.

DOI:10.1523/JNEUROSCI.2695-14.2015

Copyright $\odot 2015$ the authors $\quad 0270-6474 / 15 / 354676-07 \$ 15.00 / 0$
Nagahara and Tuszynski, 2011; Autry and Monteggia, 2012; Li and Pozzo-Miller, 2014). Despite the diverse and pivotal roles of BDNF in the brain, the mechanisms by which BDNF, or more generally speaking, neurotrophins regulate synaptic transmission, particularly the presynaptic component, remain poorly understood.

Here we investigated how BDNF regulates presynaptic functions at the calyx of Held, a glutamatergic nerve terminal, in which electrophysiological recordings of calcium channels, exocytosis, and endocytosis can be performed (Borst and Soria van Hoeve, 2012). We found that BDNF inhibits calcium channel activation, exocytosis, and endocytosis. These findings are the first direct evidence of neurotrophic regulation of presynaptic functions, which may contribute to the multiple roles of neurotrophins in the brain.

\section{Materials and Methods}

Slice preparation, solutions, and electrophysiology. The measurements of presynaptic calcium current $\left(I_{\mathrm{Ca}}\right)$ and membrane capacitance $\left(C_{\mathrm{m}}\right)$ and the EPSCs were described previously (Wu et al., 2009). Briefly, parasagittal brainstem slices ( $200 \mu \mathrm{m}$ thick) containing the medial nucleus of the trapezoid body (MNTB) were prepared from postnatal 7 (P7) to P14 Wistar rats of either sex. Animal protocols followed the guidelines of the National Institutes of Health. Slices were cut in an ice-cold solution containing the following (in mM): $125 \mathrm{NaCl}, 25 \mathrm{NaHCO}_{3}, 25$ dextrose, $2.5 \mathrm{KCl}, 1.25 \mathrm{NaH}_{2} \mathrm{PO}_{4}, 0.1 \mathrm{CaCl}_{2}, 3 \mathrm{MgCl}_{2}, 0.4$ ascorbic acid, 3 myoinositol, and 2 sodium pyruvate, $\mathrm{pH} 7.4$ (when bubbled with $95 \% \mathrm{O}_{2}$ and $5 \% \mathrm{CO}_{2}$ ). Slices were incubated for $30 \mathrm{~min}$ at $37^{\circ} \mathrm{C}$ and then held at room temperature $\left(22-24^{\circ} \mathrm{C}\right)$. Whole-cell presynaptic recordings were performed at room temperature using bath solution containing the following (in mM): $105 \mathrm{NaCl}, 25 \mathrm{NaHCO}_{3}, 25$ glucose, $2.5 \mathrm{KCl}, 1.25 \mathrm{NaH}_{2} \mathrm{PO}_{4}$, $2 \mathrm{CaCl}_{2}, 1 \mathrm{MgCl}_{2}, 0.4$ ascorbic acid, 3 myo-inositol, 2 sodium pyruvate, 

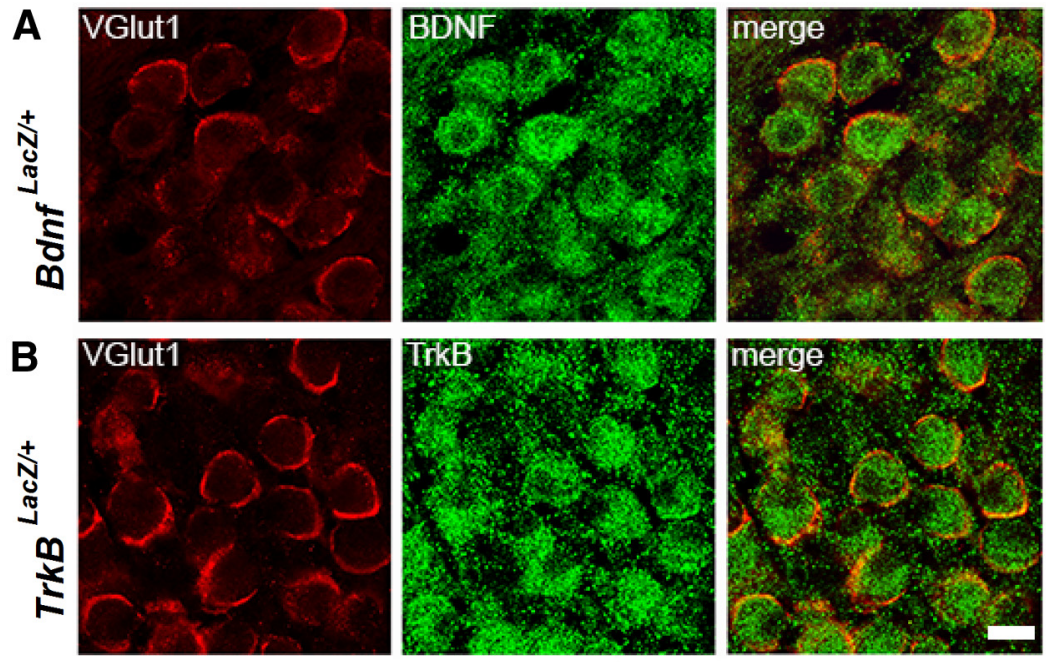

C

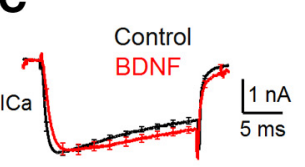

D

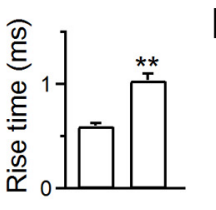

E
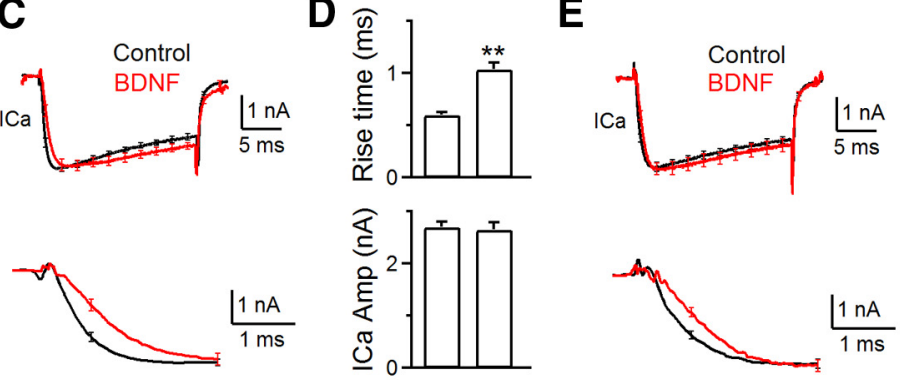

P8-10

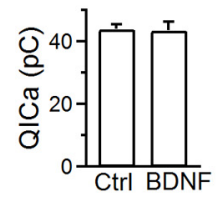

P13-14

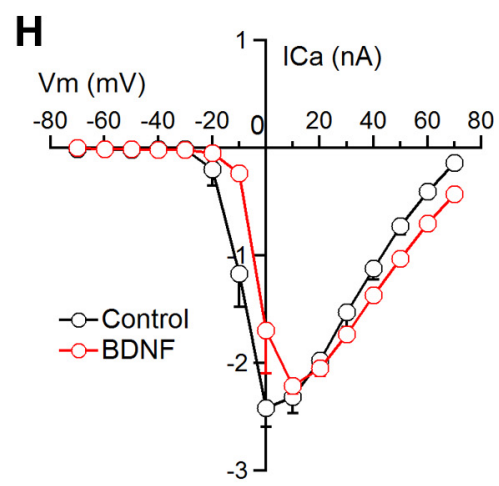

Figure 1. BDNF slows down $I_{\mathrm{Ca}_{\mathrm{a}}}$ activation kinetics. $A, B$, Antibody staining of $v$ Glut 1 (red) and $\beta$-galactosidase (green) to label the calyx and BDNF, respectively, in Bdnf ${ }^{\text {lacZ/ }++}(\boldsymbol{A})$ and TrkB in TrkB ${ }^{\text {LacZ/+ }}(\boldsymbol{B})$ knock-in mice at P14. Scale bar, $10 \mu \mathrm{m}$. $\boldsymbol{C}$, Top,

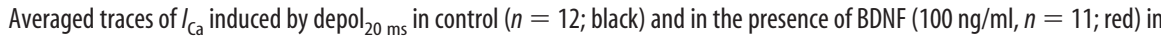
P8-P10 rat calyces (mean \pm SEM; SEM is plotted every $2 \mathrm{~ms}$ ). Bottom, Same traces as in the top but showing the rise phase on a larger timescale. $\boldsymbol{D}, I_{\mathrm{Ca}} 20-80 \%$ rise time, $I_{\mathrm{Ca}}$ amplitude, and $\mathrm{Q} I_{\mathrm{Ca}}$ (mean \pm SEM) induced by depol ${ }_{20 \mathrm{~ms}}$ in control $(C \mathrm{Ctr} ; ; n=12)$ and in the presence of BDNF $(100 \mathrm{ng} / \mathrm{ml}, n=11)$ in P8 $-P 10$ calyces. ${ }^{* *} p<0.01 . E$, $\boldsymbol{F}$, Similar plots as in $C$ and $\boldsymbol{D}$, respectively, but from P13-P14 calyces (control, $n=12 ; \mathrm{BDNF}, n=10)$. G, Sampled $I_{\mathrm{Ca}}$ traces in response to $200 \mathrm{~ms}$ depolarization from -80 to -40 (gray), -10 (blue), 0 (pink), 10 (green), and 40 (black) $\mathrm{mV}$ in control and BDNF-treated calyces at P9. $\boldsymbol{H}, I-V$ relationship in control and BDNF-treated P8-P10 calyces ( $n=3$ for each data point).

0.1 3,4-diaminopyridine, 0.05 D-APV, 0.001 TTX, and 20 tetraethylammonium (used to isolate $I_{\mathrm{Ca}}$ ), $\mathrm{pH} 7.3$ adjusted with $\mathrm{NaOH}$ or $\mathrm{HCl}$, osmolarity: 300-320 mOsm. The presynaptic pipette (3-5 M 2 ) solution contained the following (in mM): 125 Cs-gluconate, $20 \mathrm{CsCl}, 4 \mathrm{Mg}$-ATP, 0.3 GTP, 10 Na-phosphocreatine, 10 HEPES, and 0.05 BAPTA, pH 7.2 adjusted with $\mathrm{CsOH}$ (osmolarity, 300-310 mOsm). The measurements

\section{$\mathbf{F}$}
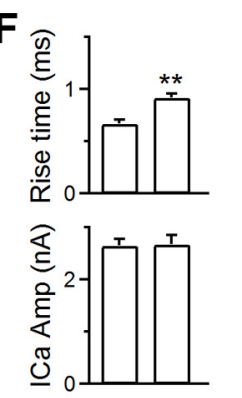

of presynaptic $I_{\mathrm{Ca}}$ and $C_{\mathrm{m}}$ were made with EPC-10 amplifier and the software lock-in amplifier (PULSE; HEKA), implementing Lindau-Neher's technique (Sun and $\mathrm{Wu}$, 2001). The sinusoidal stimulus frequency was $1000 \mathrm{~Hz}$ with a peak-to-peak voltage $\leq 60 \mathrm{mV}$. The holding potential for presynaptic and postsynaptic recordings was $-80 \mathrm{mV}$.

For EPSC recordings, horizontal brainstem slices containing the MNTB were prepared. The EPSC was induced by a single afferent stimulus applied via a bipolar electrode (5-20 $\mathrm{V}, 100 \mu \mathrm{s})$ placed at the midline of the trapezoid body in which axons connected with calyces pass. The stimulation interval was $5 \mathrm{~s}$. The EPSC was recorded with an Axopatch 200B amplifier (Molecular Devices) via a pipette (2-3 $\mathrm{M} \Omega$ ) containing the following (in $\mathrm{mm}$ ): $125 \mathrm{~K}$-gluconate, $20 \mathrm{KCl}, 4 \mathrm{MgATP}, 10 \mathrm{Na} 2-$ phosphocreatine, 0.3 GTP, 10 HEPES, and 0.5 EGTA, pH 7.2, adjusted with $\mathrm{KOH}$. The series resistance $<12 \mathrm{M} \Omega$ was compensated by $90 \%$ (10 $\mu$ s lag).

Human recombinant BDNF (EMD Millipore) was applied in bath solution at $100 \mathrm{ng} / \mathrm{ml}$. In some experiments, the TrkB inhibitor K252a (200 nM) was coapplied with BDNF in bath solution.

Immunohistochemistry. Brains of Bdnf $f^{L a c Z /+}$ or $\operatorname{Trk} B^{\text {LacZ/+ }}$ P14 mice were embedded in OCT (Electron Microscopy Sciences) and sectioned using a cryostat (CM3050S; Leica) at 30 $\mu \mathrm{m}$. Sections containing calyces were permeabilized with $0.3 \%$ Triton X-100 and subsequently incubated with the primary antibodies overnight at $4^{\circ} \mathrm{C}$ [guinea pig anti-vesicular glutamate transporter 1 (vGlut1), 1:5000 (Millipore); rabbit anti- $\beta$-galactosidase, 1:2000 (Cappel)]. After rinses in PBS, sections were incubated with fluorescence-conjugated secondary antibodies (rhodamine-conjugated donkey anti-guinea pig and DyLight 488 donkey anti-rabbit, 1:200; Jackson ImmunoResearch) for $2 \mathrm{~h}$ at room temperature. Mounted sections were imaged with an inverted confocal microscope (TCS SP5II; Leica; 60× oilimmersion objective, 1.4 numerical aperture). Green (excitation, 488; emission, 498-520 $\mathrm{nm}$ ) and red (excitation, 561; emission, 570$620 \mathrm{~nm}$ ) fluorescence signals were acquired sequentially. Calyx labeling by vGlut 1 antibody was evident as judged by eye (Fig. $1 A$ ).

Data analysis. Data were presented as mean \pm SEM and analyzed using Student's $t$ test. Capacitance was measured within $10 \mathrm{~min}$ after whole-cell break-in. To avoid capacitance artifacts (Wu et al., 2005; Yamashita et al., 2005), capacitance jumps were measured at $200 \mathrm{~ms}$ after depolarization. The $\tau$ was measured from the monoexponential or biexponential fit. The initial rate of capacitance decay ( Rate $_{\text {decay }}$ ) was measured within $4 \mathrm{~s}$ after $20 \mathrm{~ms}$ depolarization from -80 to $10 \mathrm{mV}\left(\operatorname{depol}_{20 \mathrm{~ms}}\right)$ or 20 action potential-equivalent stimuli (APe; 1 ms depolarization from -80 to $7 \mathrm{mV}$ ) at 100 $\mathrm{Hz}$ that induced slow endocytosis but within $1-1.5 \mathrm{~s}$ after $10 \mathrm{depol}_{20 \mathrm{~ms}}$ at $10 \mathrm{~Hz}\left(\right.$ depol $\left._{20 \mathrm{~ms} \times 10}\right)$ or $200 \mathrm{APe}$ at $100 \mathrm{~Hz}$ that induced rapid endocytosis. We used depol $20 \mathrm{~ms} \times 10$ or $200 \mathrm{APe}$ at $100 \mathrm{~Hz}$ to induce rapid endocytosis, because the Rate decay $_{\text {after }}$ depol $_{20 \mathrm{~ms} \times 10}$ reflected mostly $(\sim 80 \%)$ the rapid component of endocytosis (Wu et al., 2005, 2009; Sun et al., 2010). 


\section{Results}

$\mathrm{BDNF}$ and TrkB receptor in calyces

We examined $B d n f$ and TrkB gene expression at calyces using $B d n f^{\mathrm{LacZ/+}}$ and Trk$B^{\text {LacZ/+ }}$ knock-in mouse strains (Xu et al., 2000a; Gorski et al., 2003), respectively. In these mouse strains, $\beta$-galactosidase expression is under control of the $B d n f$ or TrkB promoter. The antibody against $\beta$-galactosidase, which indicates $B d n f$ or TrkB gene expression, overlapped partially with the staining of an antibody against vGlut 1 that labels the calyx of Held in $B d n f^{\text {LacZ/+ }}$ and TrkB $B^{\text {LacZ/+ }}$ knock-in mice (P14; Fig. $1 A, B$ ), suggesting that $\mathrm{BDNF}$ and TrkB are expressed in calyces. The large part of $\beta$-galactosidase staining did not overlap with vGlut1 staining but was observed at the postsynaptic cell body (Fig. $1 A, B$ ), suggesting that BDNF and TrkB are also expressed in postsynaptic neurons.

\section{BDNF slows down $I_{\mathrm{Ca}}$ activation}

Knowing that BDNF and TrkB are present at calyces, we examined how BDNF affects whole-cell $I_{\mathrm{Ca}}$ induced by a $20 \mathrm{~ms}$ depolarization from -80 to $10 \mathrm{mV}$ (applies if not mentioned otherwise; depol $_{20} \mathrm{~ms}$ ) in rat calyces. In control P8-P10 rats, a depol $20 \mathrm{~ms}$ induced an $I_{\mathrm{Ca}}$ of $2.73 \pm 0.10 \mathrm{nA}$ (during depolarization) with a $20-80 \%$ rise time of $0.60 \pm 0.03 \mathrm{~ms}$ ( $n=12$ calyces $)$. The tail current was $2.9 \pm 0.12 \mathrm{nA}(n=12)$. In the presence of BDNF (100 ng/ml, bath application, 20-40 $\mathrm{min}$ ), the amplitude of $I_{\mathrm{Ca}}$ induced by depol $20 \mathrm{~ms}$ (during depolarization, $2.66 \pm 0.15 \mathrm{nA}$; tail current, $3.3 \pm$ $0.18 \mathrm{nA}, n=11)$ was similar to control $(p>0.05)$, but the $20-80 \%$ rise time $(0.98 \pm 0.08 \mathrm{~ms}, n=11)$ was significantly slower than control $(p<0.01$; Fig. $1 C, D)$. A slower $I_{\mathrm{Ca}}$ rise time was observed not only before hearing onset in P8-P10 immature calyces containing $\mathrm{P} / \mathrm{Q}-, \mathrm{N}$-, and R-type channels (Fig. 1C,D; Wu et al., $1998,1999)$ but also in more matured post-hearing P13-P14 calyces (Fig. 1 E,F)

containing only P/Q-type channels (Iwasaki et al., 2000; Borst and Soria van Hoeve, 2012). Thus, calcium channels affected by BDNF include P/Q type.

Calcium may facilitate or inactivate $I_{\mathrm{Ca}}$ (Borst and Soria van Hoeve, 2012). This calcium-dependent feature did not significantly affect measurements of the $I_{\mathrm{Ca}}$ amplitude, because dialysis of $10 \mathrm{~mm}$ BAPTA in calyces did not affect peak $I_{\mathrm{Ca}}$ during $\operatorname{depol}_{20 \mathrm{~ms}}(2.45 \pm 0.13 \mathrm{nA}, n=12)$ compared with control (2.73 $\pm 0.10 \mathrm{nA}, n=12, p>0.05 ; \mathrm{Xu}$ and $\mathrm{Wu}, 2005$; $\mathrm{Wu}$ et al., 2009).

To determine whether BDNF affects the calcium channel current-voltage relationship $(I-V)$, we applied a $200 \mathrm{~ms}$ depolarization from -80 to $-70,-60, \ldots$ to $50 \mathrm{mV}$ with an interval of $\sim 30$ $\mathrm{s}$ and found that, at -10 and $0 \mathrm{mV}, I_{\mathrm{Ca}}$ amplitude in the presence
P8-10
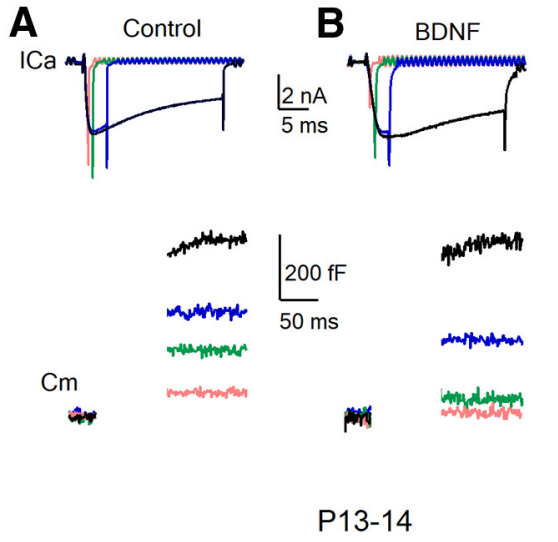

F
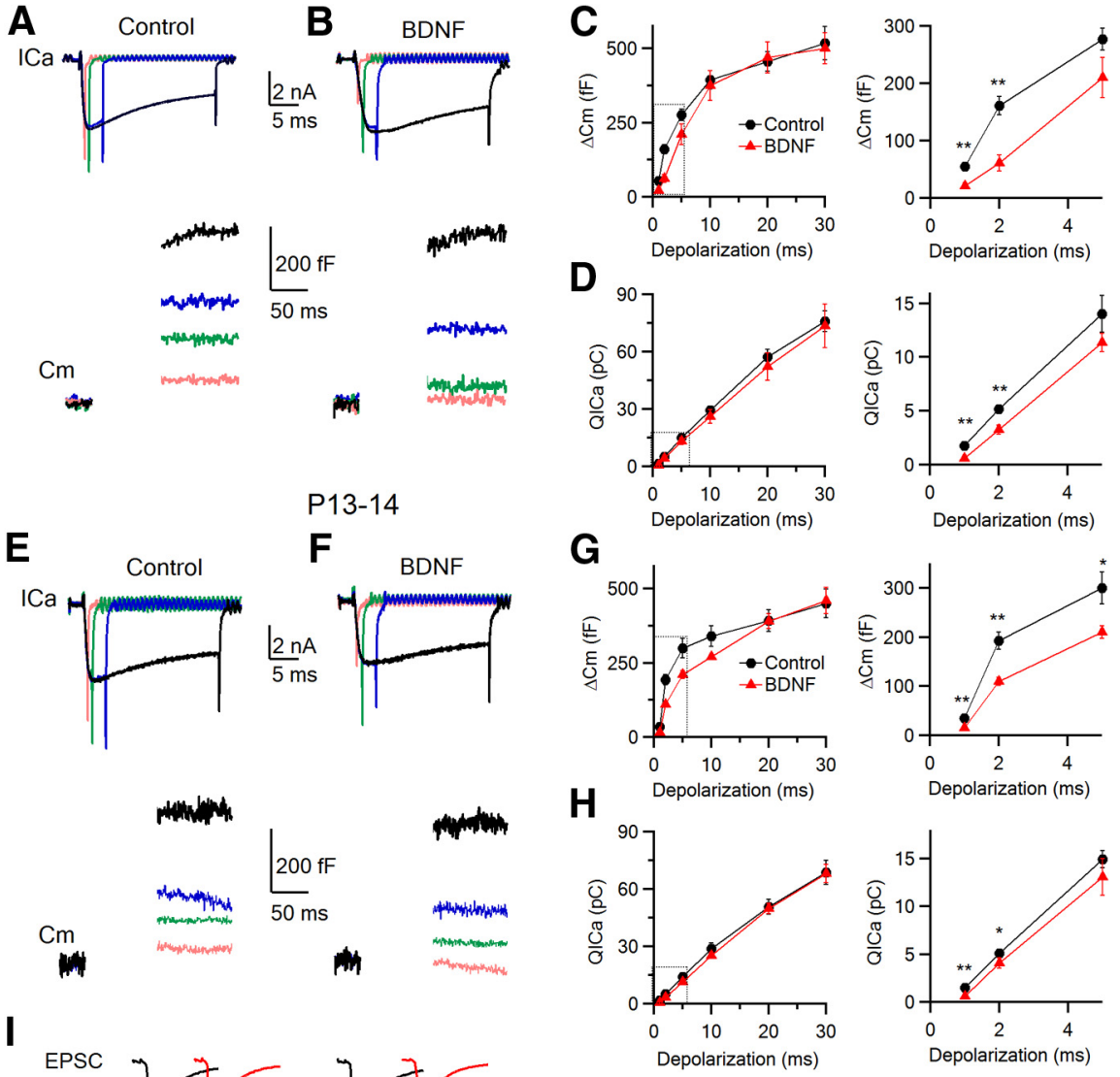

Figure 2. BDNF reduces the release probability of vesicles in the RRP by reducing $Q I_{\mathrm{Ca}} \cdot A, B$, Sampled $I_{\mathrm{Ca}}$ and capacitance $\left(C_{\mathrm{m}}\right)$ changes induced by 1 (pink), 2 (green), 5 (blue), and 30 (black) ms depolarization from a P9 calyx in the absence ( $\boldsymbol{A}$, Control) or presence (B) of BDNF. Capacitance within $100 \mathrm{~ms}$ after depolarization was not shown to avoid artifacts (Yamashita et al., 2005). $\boldsymbol{C}$ mean \pm SEM; red) of BDNF. ${ }^{*} p<0.05,{ }^{* *} p<0.01$. The dotted box on the left is enlarged on the right. $\boldsymbol{E}-\boldsymbol{H}$, Similar to $\boldsymbol{A}-\boldsymbol{D}$, respectively, but from P13-P14 calyces (control, $n=5 ;$ BDNF, $n=4$ ). I, Sampled EPSCS (top) and EPSC amplitude (mean \pm SEM; bottom) taken 5-10 min before and 30 - 40 min after applying a control solution (control; black) or BDNF (red).

of BDNF was most significantly smaller than those in the absence of BDNF (Fig. 1G,H). The $I-V$ relationship in the presence of BDNF shifted to the right compared with that in the absence of BDNF (Fig. $1 H$ ), consistent with a slower $I_{\mathrm{Ca}}$ rise in the presence of BDNF.

\section{BDNF inhibits exocytosis}

To study how BDNF affects exocytosis, we measured the capacitance jump $\left(\Delta C_{\mathrm{m}}\right)$ induced by $1-30 \mathrm{~ms}$ depolarization in $\mathrm{P} 8-\mathrm{P} 10$ calyces in the absence (control) or presence of BDNF (Fig. 2A$D)$. In control, the $\Delta C_{\mathrm{m}}$ and the $I_{\mathrm{Ca}}$ charge $\left(Q I_{\mathrm{Ca}}\right)$ increased as the depolarization duration increased from 1 to $5 \mathrm{~ms}$, and then the $\Delta C_{\mathrm{m}}$ approached saturation at longer depolarization whereas the $Q I_{\mathrm{Ca}}$ continued to increase (Fig. $2 A, C, D$ ), consistent with the finding that a readily releasable pool (RRP) is depleted by $20-30$ 


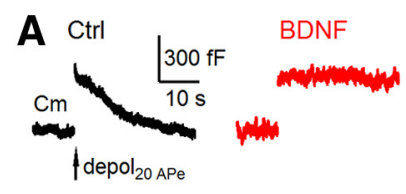

B
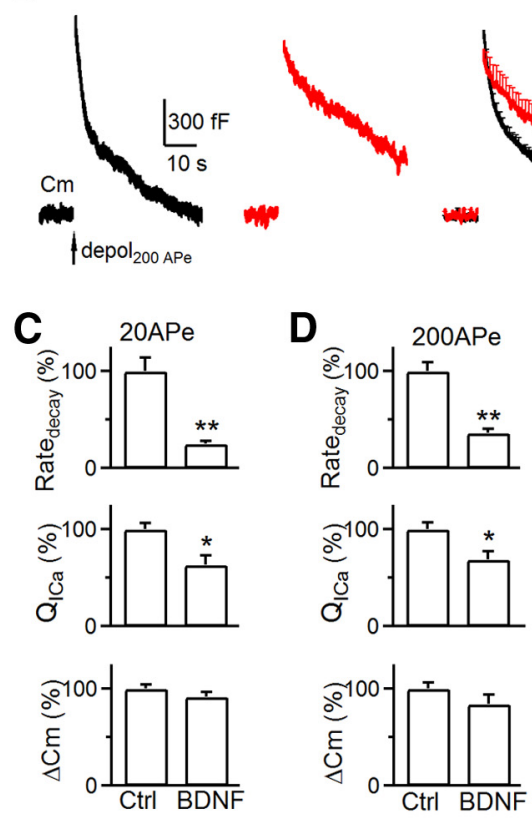
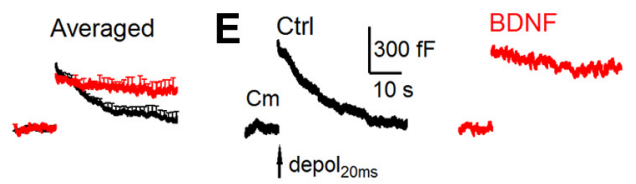

$\mathbf{F}$
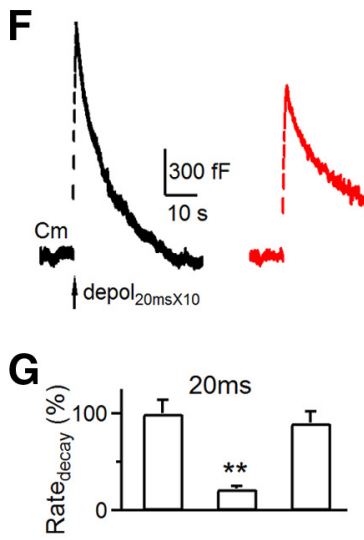
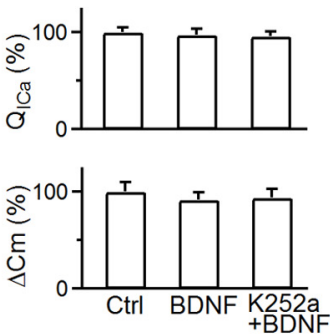
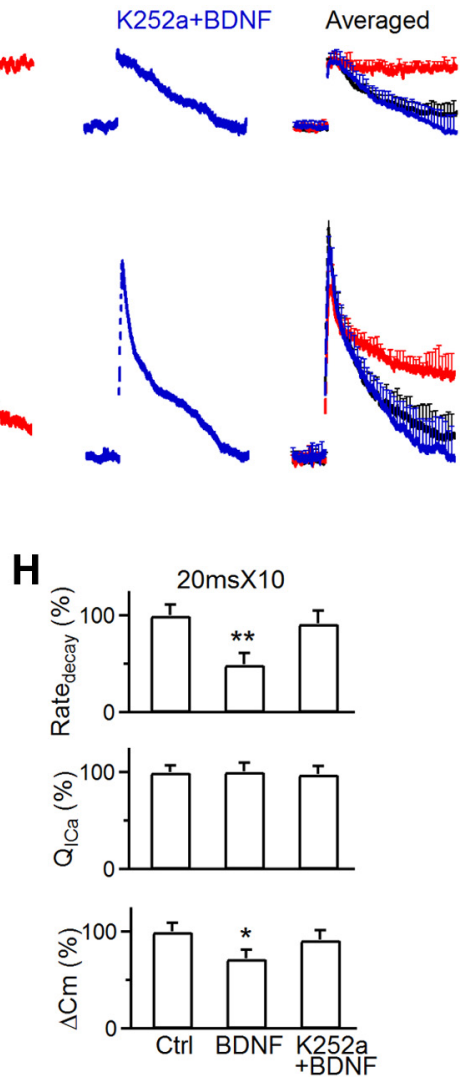

Figure 3. BDNF inhibits slow and rapid endocytosis in P8-P10 calyces. $A$, Sampled and averaged (mean \pm SEM) $C_{\mathrm{m}}$ changes induced by $20 \mathrm{APe}$ at $100 \mathrm{~Hz}$ (arrow) in control (Ctrl; $n=6$; black) and in the presence of BDNF (100 ng/ml, $n=4$; red) in P8-P10 calyces (P8-P10 applies to all panels). The averaged traces are superimposed (right), and SEM is plotted every 1 s. B, Similar arrangement as in $A$, except the stimulus was $200 \mathrm{APe}$ at $100 \mathrm{~Hz}$. Control, $n=6 ; B D N F, n=4$. C, Rate decay' $\mathrm{Q}_{\mathrm{Ca}^{\prime}}$ and $\Delta C_{\mathrm{m}}$ induced by $20 \mathrm{APe}$ at $100 \mathrm{~Hz}$ in control (Ctrl; $\left.n=5\right)$ and in the presence of BDNF $(n=4) .{ }^{*} p<0.05 ;{ }^{* *} p<0.01$. D, Similar to $\boldsymbol{C}$, except that the stimulus was $200 \mathrm{APe}$ at $100 \mathrm{~Hz}$. $\boldsymbol{E}, \boldsymbol{F}$, Sampled (left 3 panels) and averaged $C_{\mathrm{m}}$ (right) changes induced by depol $20 \mathrm{~ms}(\boldsymbol{E})$ or $\operatorname{depol}_{20 \mathrm{~ms} \times 10}(\boldsymbol{F})$ in control $(n=6$; black), in the presence of BDNF $(100 \mathrm{ng} / \mathrm{ml}, n=4$; red), or in the presence of K252a ( $200 \mathrm{~nm})$ and BDNF $(n=4$; blue). The averaged traces are superimposed

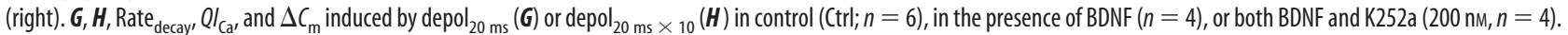

ms depolarization (Wu and Borst, 1999; Sakaba and Neher, 2001; $\mathrm{Xu}$ and $\mathrm{Wu}, 2005$; Wu et al., 2009).

In the presence of BDNF (100 ng/ml; Fig. $2 B$ ), the $\Delta C_{\mathrm{m}}$ and $Q I_{\mathrm{Ca}}$ were significantly lower than control after 1-2 ms depolarization $(p<0.01)$ but similar after $10-30 \mathrm{~ms}$ depolarization that depletes the RRP and thus reflects its size (Fig. $2 B-D$ ). Because BDNF did not affect the RRP, it must reduce the $\Delta C_{\mathrm{m}}$ induced by 1-2 ms depolarization through reduction of the release probability of RRP vesicles. The reduction of the release probability was caused by the decrease of $I_{\mathrm{Ca}}$, given that $I_{\mathrm{Ca}}$ was reduced by BDNF. Similar results were obtained in P13-P14 calyces (Fig. $2 E-H)$. The decrease of $I_{\mathrm{Ca}}$ induced by $1-2 \mathrm{~ms}$, but not $10-30$ ms depolarization was attributable to the slowdown of $I_{\mathrm{Ca}}$ rise by BDNF as shown during $\operatorname{depol}_{20 \mathrm{~ms}}$ (Fig. $1 C-F$ ). Thus, BDNF inhibits the release probability of the RRP vesicle during brief depolarization by reducing $I_{\mathrm{Ca}}$ via slowing down the kinetics of calcium channel activation in $\mathrm{P} 8$-P14 calyces.

To examine whether the presynaptic effects of BDNF have an effect on synaptic transmission, we recorded the EPSCs (see Materials and Methods) in the absence (control group) or presence (BDNF group) of BDNF. In the control group, the EPSC was $7.40 \pm 0.55 \mathrm{nA}(n=3)$ at $5-10 \mathrm{~min}$ of recording but increased to $9.37 \pm 1.02 \mathrm{nA}(n=3)$ at $30-40 \mathrm{~min}$ afterward (Fig. 2I, black). For the BDNF group, we applied BDNF after the EPSC was recorded for 5-10 min. The EPSC before BDNF application was $7.33 \pm 0.98$ $\mathrm{nA}(n=4)$, similar to the control group, but decreased significantly to $5.45 \pm 0.52 \mathrm{nA}(n=4, p<0.05$, paired $t$ test $)$ at $30-40 \mathrm{~min}$ after
BDNF application (Fig. 2I, red), which was $\sim 40 \%$ less compared with the control group within the same timeframe $(p<0.05)$. Although recording the EPSC alone is difficult to distinguish between presynaptic and postsynaptic effects of BDNF, the EPSC reduction (Fig. 2I) was in the same order as the $\Delta C_{\mathrm{m}}$ reduction (Fig. 2C), suggesting that $\mathrm{BDNF}$ inhibits the EPSC by reducing vesicle release. A slightly larger extent of $\Delta C_{\mathrm{m}}$ reduction might be attributable to the differences in recording conditions, such as the stimulation protocols, recording methods, and perhaps effects of BDNF on other channels or postsynaptic cells.

\section{BDNF inhibits slow and rapid endocytosis}

After exocytosis, fused vesicles are retrieved via endocytosis for recycling. Here we determined whether BDNF modulates two commonly observed forms of endocytosis: slow and rapid endocytosis (L. G. Wu et al., 2014). In P8-P10 calyces, 20 APe (1 ms from -80 to $7 \mathrm{mV}$; Wu et al., 2009) at $100 \mathrm{~Hz}$ induced a $\Delta C_{\mathrm{m}}$ of $395 \pm 18 \mathrm{fF}$, followed by a slow monoexponential decay with a $\tau$ of $15.6 \pm 1.1 \mathrm{~s}$ and an initial Rate decay $_{\text {of }} 27 \pm 3.7 \mathrm{fF} / \mathrm{s}(n=6$; Fig. $3 A, C)$. Although both $\tau$ and Rate decay $_{\text {reflected endocytosis rate, }}$ we used mostly Rate decay $_{\text {because }} \tau$ was often too slow to estimate when endocytosis is blocked (Wu et al., 2009; Sun et al., 2010). In

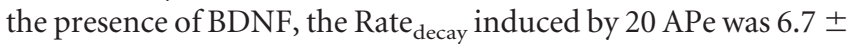
$0.8 \mathrm{fF} / \mathrm{s}(n=4$ calyces; Fig. $3 A, C), \sim 25 \%$ of control $(p<0.01)$, suggesting that BDNF inhibits slow endocytosis.

We induced rapid endocytosis with $200 \mathrm{APe}$ at $100 \mathrm{~Hz}$ (Wu et al., 2005; Sun et al., 2010; X. S. Wu et al., 2014). In control, 200 

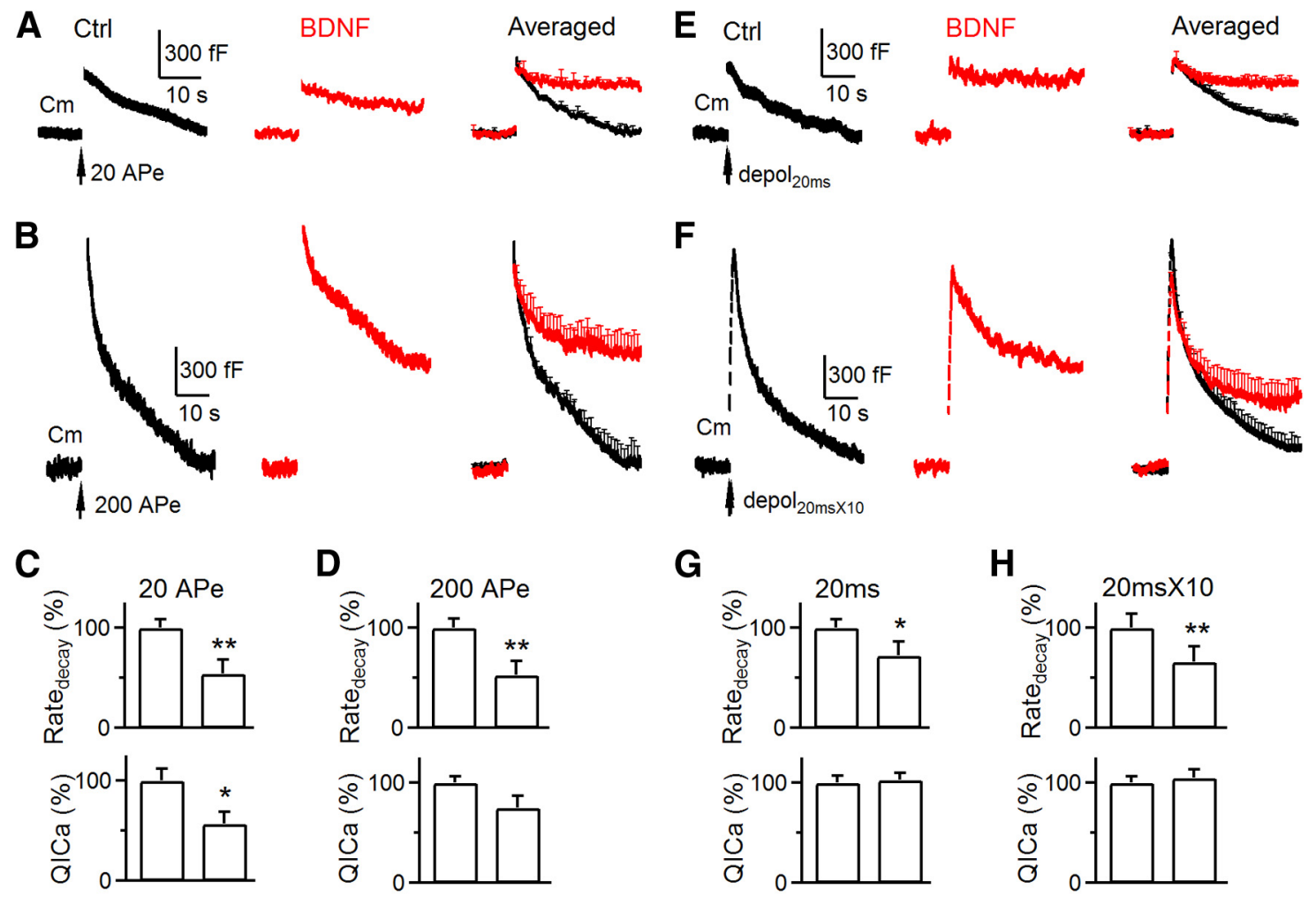

G
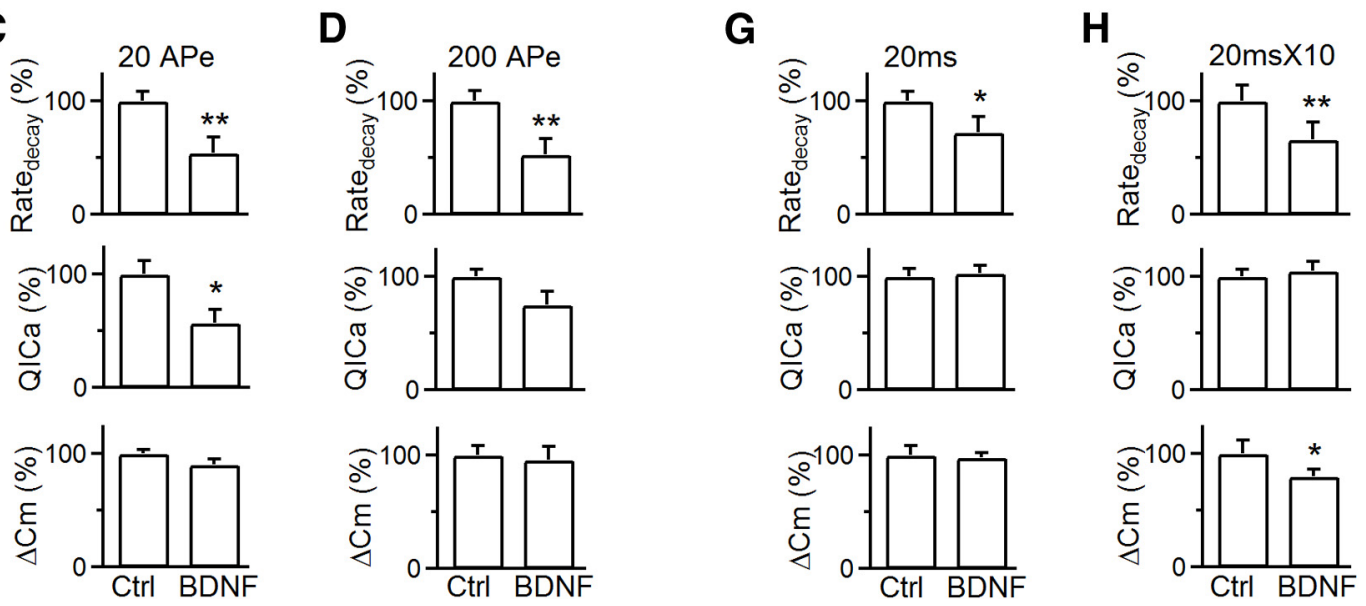

Figure 4. BDNF inhibits slow and rapid endocytosis in P13-P14 calyces. $\boldsymbol{A}-\boldsymbol{H}$, Similar arrangements as Figure $3 A-H$, respectively, but from P13-P14 calyces. $\boldsymbol{A}, \boldsymbol{B}, \mathrm{Control}(\mathrm{Ctrl}), \boldsymbol{n}=4$; $\mathrm{BDNF}, \boldsymbol{n}=$ 4. C, $\boldsymbol{D}$, Control, $n=6$; BDNF, $n=4$. $\boldsymbol{E}, \boldsymbol{F}$, Control, $n=6$; BDNF, $n=4$. G, $\boldsymbol{H}$, Control, $n=5 ;$ BDNF, $n=4 .{ }^{*} p<0.05 ;{ }^{* *} p<0.01$.

APe induced a $\Delta C_{\mathrm{m}}$ of $1190 \pm 76 \mathrm{fF}$, followed by a biexponential decay with $\tau$ of $2.05 \pm 0.1 \mathrm{~s}(33 \pm 4 \%)$ and $19.8 \pm 1.5 \mathrm{~s}(n=6$ calyces; Fig. $3 B)$, respectively. The Rate decay $_{\text {after }} \Delta C_{\mathrm{m}}$ was $180 \pm$ $16 \mathrm{fF} / \mathrm{s}(n=6$ calyces; Fig. $3 D)$, which reflected mostly $(>80 \%)$ the rapid component of endocytosis (Wu et al., 2005; Sun et al., 2010). In the presence of BDNF, $200 \mathrm{APe}$ induced a $\Delta C_{\mathrm{m}}$ of $1000 \pm 119 \mathrm{fF}$ and a Rate decay $_{\text {of }} 65 \pm 7 \mathrm{fF} / \mathrm{s}$, which was $\sim 35 \%$ of control $(p<0.01)$, suggesting that BDNF inhibits rapid endocytosis $(n=4$ calyces; Fig. $3 B, D)$.

Because endocytosis is triggered by calcium influx and the Rate $_{\text {decay }}$ depends on $Q I_{\mathrm{Ca}}$ in calyces (Hosoi et al., 2009; Wu et al., 2009; Xue et al., 2012), the reduction of $Q I_{\mathrm{Ca}}$ might at least partially account for the Rate $_{\text {decay }}$ reduction. To determine whether a $Q I_{\mathrm{Ca}}$-independent mechanism contributes to the reduced Rate $_{\text {decay, }}$ we used a depol 20 ms to induce slow endocytosis (Wu et al., 2005, 2009; Sun et al., 2010), which induced a similar $Q I_{\mathrm{Ca}}$ in control and BDNF-treated calyces at P8-P10 ( $n=4-6$ calyces; Fig. $3 E, G$; see also Fig. $1 D$ ). The Rate decay $_{\text {in control was similar to }}$

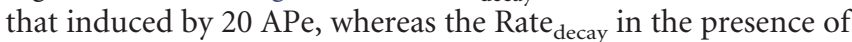
BDNF was only $\sim 22 \%$ of control (Fig. $3 E, G$ ), suggesting that BDNF inhibits endocytosis primarily by a calcium-independent mechanism. Similarly, BDNF did not reduce $Q I_{\mathrm{Ca}}$ but reduced the Rate $_{\text {decay }}$ induced by a train of 10 depol $_{20 \mathrm{~ms}}$ at $10 \mathrm{~Hz}\left(\right.$ depol $_{20 \mathrm{~ms} \times 10}$; Fig. $3 F, H)$, which mostly reflects $(>80 \%)$ rapid endocytosis in control (Wu et al., 2005, 2009; Sun et al., 2010). These results suggest that BDNF inhibits rapid endocytosis primarily by a $Q I_{\mathrm{Ca}}$-independent mechanism.
To determine whether the effect of BDNF on endocytosis is mediated via TrkB receptors, we applied the TrkB inhibitor K252a (200 $\mathrm{nM}$, bath application), together with BDNF (100 ng/ml). In this condition, Rate decay $_{\text {induced by depol }} 20 \mathrm{~ms}$ or $\operatorname{depol}_{20 \mathrm{~ms} \times 10}$ was similar to control, indicating that K252a blocks inhibition of endocytosis by BDNF (Fig. $3 E-H$ ). Thus, BDNF inhibits endocytosis by activation of TrkB.

Inhibition of slow and rapid endocytosis was not only observed in P8-P10 calyces (Fig. 3) but also in P13-P14 calyces (Fig. $4 A-H)$, suggesting that BDNF inhibits endocytosis primarily by a calcium-independent mechanism in both pre-hearing and posthearing calyces.

BDNF reduced the $\Delta C \mathrm{M}$ induced by $\operatorname{depol}_{20 \mathrm{~ms}} \times{ }_{10}$ (Figs. $3 H$, $4 H$ ) but not that by $\operatorname{depol}_{20 \mathrm{~ms}}$ (Figs. $3 G, 4 G$ ). The $\Delta C_{\mathrm{m}}$ induced by depol $_{20 \mathrm{~ms}}$ reflects the RRP size, whereas the $\Delta C_{\mathrm{m}}$ induced by depol $_{20 \mathrm{~ms}} \times{ }_{10}$ reflects the sum of all vesicles mobilized to the $\mathrm{RRP}$ during depol $20 \mathrm{~ms} \times 10$ that repeatedly depletes the RRP $(\mathrm{Wu}$ and Borst, 1999; Sakaba and Neher, 2001; Xu and Wu, 2005; Wu et al., 2009). Thus, a reduction of the $\Delta C_{\mathrm{m}}$ induced by depol $_{20 \mathrm{~ms}} \times 10$ may reflect a reduced vesicle mobilization to the RRP. Because blocking endocytosis inhibits vesicle mobilization to the RRP, endocytosis may facilitate vesicle mobilization to the RRP by clearance of active zones perturbed by exocytosed vesicle membrane and proteins (Kawasaki et al., 2000; Hosoi et al., 2009; Wu et al., 2009; Hua et al., 2011; L. G. Wu et al., 2014). Thus, we suggest that BDNF reduces the $\Delta C_{\mathrm{m}}$ induced by depol $\mathrm{L}_{20 \mathrm{~ms}} \times 10$ via inhibition of endocytosis and 
the active zone clearance, leading to inhibition of vesicle mobilization to the RRP.

\section{Discussion}

We report for the first time that a neurotrophin, BDNF, slows down activation of voltage-dependent calcium channels, including $\mathrm{P} / \mathrm{Q}$ type, at the calyx of Held nerve terminal (Fig. 1). By capacitance measurements and postsynaptic recordings, we provided direct evidence showing that BDNF reduces release probability and the EPSCs (Fig. 2) and inhibits both slow and rapid endocytosis (Figs. 3, 4). The effects of BDNF on release can be primarily attributed to inhibition of calcium channel activation kinetics, whereas the effects of BDNF on endocytosis is primarily calcium-independent. BDNF may also inhibit vesicle mobilization to the RRP via inhibition of endocytosis and thus the active zone clearance (Figs. 3F,H, 4F,H). These findings show diverse regulatory roles of BDNF in presynaptic functions.

Our findings of the effects of BDNF on nerve terminals provide new mechanisms underlying diverse functions of BDNF in the nervous system, such as neuronal survival, differentiation, axonal branching, dendritic growth, synapse development, and synaptic plasticity (Huang and Reichardt, 2001). The reduction of release probability by BDNF may decrease synaptic strength, which may regulate synapse development and neuronal wiring. Deficiency in BDNF signaling leads to axonal atrophy and neurodegeneration, which are associated with increased intracellular calcium and excitotoxicity. Thus, inhibition of calcium influx during brief depolarization by BDNF might play a role in neuronal protection and present a potential target in treating neurodegenerative disorders.

Multiple studies show that BDNF potentiates excitatory transmission in the cortex and hippocampus, leading to a long-term potentiation (Park and Poo, 2013). However, several studies suggest that, in the brainstem, BDNF may play a different role (Balkowiec et al., 2000; Kline et al., 2010; Clark et al., 2011). In the medial nucleus tractus solitarius that receives cardiovascular afferent input, BDNF regulates cardiovascular responses, such as blood pressure and heart rate, by inhibiting excitatory transmission (Clark et al., 2011). Interestingly, patients or mouse models of Rett syndrome, a neurodevelopmental disorder, exhibit decreased BDNF expression, severe autonomic dysfunctions (Wang et al., 2006; Weese-Mayer et al., 2006), and defects in the auditory system (Pillion et al., 2003) in which the calyx of Held is crucial in sound localization (Borst and Soria van Hoeve, 2012). Thus, BDNF might be a potential therapeutic target for Rett syndrome.

How does BDNF slow calcium channel activation and endocytosis? BDNF may activate TrkB downstream pathways, such as phospholipase $\mathrm{C} \gamma$, that may activate $\mathrm{Ca} /$ calmodulin-dependent kinases, which may regulate calcium channels (Lee et al., 2003; Catterall and Few, 2008). Understanding the TrkB downstream pathways that regulate calcium channels and endocytosis would be of a great interest in the future.

\section{References}

Autry AE, Monteggia LM (2012) Brain-derived neurotrophic factor and neuropsychiatric disorders. Pharmacol Rev 64:238-258. CrossRef Medline

Balkowiec A, Kunze DL, Katz DM (2000) Brain-derived neurotrophic factor acutely inhibits AMPA-mediated currents in developing sensory relay neurons. J Neurosci 20:1904-1911. Medline

Borst JG, Soria van Hoeve J (2012) The calyx of held synapse: from model synapse to auditory relay. Annu Rev Physiol 74:199-224. CrossRef Medline

Carmignoto G, Pizzorusso T, Tia S, Vicini S (1997) Brain-derived neurotrophic factor and nerve growth factor potentiate excitatory synaptic transmission in the rat visual cortex. J Physiol 498:153-164. CrossRef Medline

Catterall WA, Few AP (2008) Calcium channel regulation and presynaptic plasticity. Neuron 59:882-901. CrossRef Medline

Clark CG, Hasser EM, Kunze DL, Katz DM, Kline DD (2011) Endogenous brain-derived neurotrophic factor in the nucleus tractus solitarius tonically regulates synaptic and autonomic function. J Neurosci 31:1231812329. CrossRef Medline

Frerking M, Malenka RC, Nicoll RA (1998) Brain-derived neurotrophic factor (BDNF) modulates inhibitory, but not excitatory, transmission in the CA1 region of the hippocampus. J Neurophysiol 80:3383-3386. Medline

Gorski JA, Zeiler SR, Tamowski S, Jones KR (2003) Brain-derived neurotrophic factor is required for the maintenance of cortical dendrites. J Neurosci 23:6856-6865. Medline

Hosoi N, Holt M, Sakaba T (2009) Calcium dependence of exo- and endocytotic coupling at a glutamatergic synapse. Neuron 63:216-229. CrossRef Medline

Hua Y, Sinha R, Thiel CS, Schmidt R, Hüve J, Martens H, Hell SW, Egner A, Klingauf J (2011) A readily retrievable pool of synaptic vesicles. Nat Neurosci 14:833-839. CrossRef Medline

Huang EJ, Reichardt LF (2001) Neurotrophins: roles in neuronal development and function. Annu Rev Neurosci 24:677-736. CrossRef Medline

Iwasaki S, Momiyama A, Uchitel OD, Takahashi T (2000) Developmental changes in calcium channel types mediating central synaptic transmission. J Neurosci 20:59-65. Medline

Kang H, Schuman EM (1995) Long-lasting neurotrophin-induced enhancement of synaptic transmission in the adult hippocampus. Science 267:1658-1662. CrossRef Medline

Kawasaki F, Hazen M, Ordway RW (2000) Fast synaptic fatigue in shibire mutants reveals a rapid requirement for dynamin in synaptic vesicle membrane trafficking. Nat Neurosci 3:859-860. CrossRef Medline

Kline DD, Ogier M, Kunze DL, Katz DM (2010) Exogenous brain-derived neurotrophic factor rescues synaptic dysfunction in Mecp2-null mice. J Neurosci 30:5303-5310. CrossRef Medline

Lee A, Zhou H, Scheuer T, Catterall WA (2003) Molecular determinants of $\mathrm{Ca}(2+) /$ calmodulin-dependent regulation of $\mathrm{Ca}(\mathrm{v}) 2.1$ channels. Proc Natl Acad Sci U S A 100:16059-16064. CrossRef Medline

Li W, Pozzo-Miller L (2014) BDNF deregulation in Rett syndrome. Neuropharmacology 76:737-746. CrossRef Medline

Minichiello L, Korte M, Wolfer D, Kühn R, Unsicker K, Cestari V, RossiArnaud C, Lipp HP, Bonhoeffer T, Klein R (1999) Essential role for TrkB receptors in hippocampus-mediated learning. Neuron 24:401-414. CrossRef Medline

Nagahara AH, Tuszynski MH (2011) Potential therapeutic uses of BDNF in neurological and psychiatric disorders. Nat Rev Drug Discov 10:209-219. CrossRef Medline

Orefice LL, Waterhouse EG, Partridge JG, Lalchandani RR, Vicini S, Xu B (2013) Distinct roles for somatically and dendritically synthesized brainderived neurotrophic factor in morphogenesis of dendritic spines. J Neurosci 33:11618-11632. CrossRef Medline

Park H, Poo MM (2013) Neurotrophin regulation of neural circuit development and function. Nat Rev Neurosci 14:7-23. CrossRef Medline

Pillion JP, Rawool VW, Bibat G, Naidu S (2003) Prevalence of hearing loss in Rett syndrome. Dev Med Child Neurol 45:338-343. Medline

Reichardt LF (2006) Neurotrophin-regulated signalling pathways. Philos Trans R Soc Lond B Biol Sci 361:1545-1564. CrossRef Medline

Sakaba T, Neher E (2001) Quantitative relationship between transmitter release and calcium current at the calyx of held synapse. J Neurosci 21: 462-476. Medline

Sun JY, Wu LG (2001) Fast kinetics of exocytosis revealed by simultaneous measurements of presynaptic capacitance and postsynatpic currents at a central synapse. Neuron 30:171-182. CrossRef Medline

Sun T, Wu XS, Xu J, McNeil BD, Pang ZP, Yang W, Bai L, Qadri S, Molkentin JD, Yue DT, Wu LG (2010) The role of calcium/calmodulin-activated calcineurin in rapid and slow endocytosis at central synapses. J Neurosci 30:11838-11847. CrossRef Medline

Tanaka T, Saito H, Matsuki N (1997) Inhibition of GABAA synaptic responses by brain-derived neurotrophic factor (BDNF) in rat hippocampus. J Neurosci 17:2959-2966. Medline

Vicario-Abejón C, Collin C, McKay RD, Segal M (1998) Neurotrophins induce formation of functional excitatory and inhibitory synapses between cultured hippocampal neurons. J Neurosci 18:7256-7271. Medline 
Wang H, Chan SA, Ogier M, Hellard D, Wang Q, Smith C, Katz DM (2006) Dysregulation of brain-derived neurotrophic factor expression and neurosecretory function in Mecp2 null mice. J Neurosci 26:10911-10915. CrossRef Medline

Weese-Mayer DE, Lieske SP, Boothby CM, Kenny AS, Bennett HL, Silvestri JM, Ramirez JM (2006) Autonomic nervous system dysregulation: breathing and heart rate perturbation during wakefulness in young girls with Rett syndrome. Pediatr Res 60:443-449. CrossRef Medline

Wu LG, Borst JGG (1999) The reduced release probability of releasable vesicles during recovery from short-term synaptic depression. Neuron 23: 821-832. CrossRef Medline

Wu LG, Borst JGG, Sakmann B (1998) R-type $\mathrm{Ca}^{2+}$ currents evoke transmitter release at a rat central synapse. Proc Natl Acad Sci U S A 95:47204725. CrossRef Medline

Wu LG, Westenbroek RE, Borst JGG, Catterall WA, Sakmann B (1999) Calcium channel types with distinct presynaptic localization couple differentially to transmitter release in single calyx-type synapses. J Neurosci 19: 726-736. Medline

Wu LG, Hamid E, Shin W, Chiang HC (2014) Exocytosis and endocytosis: modes, functions, and coupling mechanisms. Annu Rev Physiol 76:301331. CrossRef Medline

Wu W, Xu J, Wu XS, Wu LG (2005) Activity-dependent acceleration of endocytosis at a central synapse. J Neurosci 25:11676-11683. CrossRef Medline

Wu XS, McNeil BD, Xu J, Fan J, Xue L, Melicoff E, Adachi R, Bai L, Wu LG (2009) $\mathrm{Ca}(2+)$ and calmodulin initiate all forms of endocytosis during depolarization at a nerve terminal. Nat Neurosci 12:1003-1010. CrossRef Medline

Wu XS, Zhang Z, Zhao WD, Wang D, Luo F, Wu LG (2014) Calcineurin is universally involved in vesicle endocytosis at neuronal and nonneuronal secretory cells. Cell Rep 7:982-988. CrossRef Medline

Xu B, Zang K, Ruff NL, Zhang YA, McConnell SK, Stryker MP, Reichardt LF (2000a) Cortical degeneration in the absence of neurotrophin signaling: dendritic retraction and neuronal loss after removal of the receptor TrkB. Neuron 26:233-245. CrossRef Medline

Xu B, Gottschalk W, Chow A, Wilson RI, Schnell E, Zang K, Wang D, Nicoll RA, Lu B, Reichardt LF (2000b) The role of brain-derived neurotrophic factor receptors in the mature hippocampus: modulation of long-term potentiation through a presynaptic mechanism involving TrkB. J Neurosci 20:6888-6897. Medline

$\mathrm{Xu} \mathrm{J,} \mathrm{Wu} \mathrm{LG} \mathrm{(2005)} \mathrm{The} \mathrm{decrease} \mathrm{in} \mathrm{the} \mathrm{presynaptic} \mathrm{calcium} \mathrm{current} \mathrm{is} \mathrm{a}$ major cause of short-term depression at a calyx-type synapse. Neuron 46:633-645. CrossRef Medline

Xue L, Zhang Z, McNeil BD, Luo F, Wu XS, Sheng J, Shin W, Wu LG (2012) Voltage-dependent calcium channels at the plasma membrane, but not vesicular channels, couple exocytosis to endocytosis. Cell Rep 1:632-638. CrossRef Medline

Yamashita T, Hige T, Takahashi T (2005) Vesicle endocytosis requires dynamin-dependent GTP hydrolysis at a fast CNS synapse. Science 307: 124-127. CrossRef Medline

Zuccato C, Cattaneo E (2009) Brain-derived neurotrophic factor in neurodegenerative diseases. Nat Rev Neurol 5:311-322. CrossRef Medline 